\title{
Strategy to control occupational risk for Hepatitis B: impact on the vaccination and seroconversion rates in dentistry students
}

Estratégia para controle do risco ocupacional de Hepatite B: impacto nas taxas de vacinação e soroconversão de alunos de odontologia

Daniela Nunes NOGUEIRA ${ }^{1}$

(iD) ORCID iD 0000-0003-0904-4694

Juliana Cama RAMACCIATO2

(D) ORCID iD 0000-0002-3081-1504

Rogério Heládio Lopes MOTTA ${ }^{2}$

(iD) ORCID iD 0000-0002-6983-7883

Rui Barbosa de BRITO JÚNIOR ${ }^{3}$

(iD) ORCID iD 0000-0002-3484-9438

Almenara de Souza FONSECA-SILVA ${ }^{1}$

(iD) ORCID iD 0000-0002-0958-3391

Flávia Martão FLÓRIO 4

(iD) ORCID iD 0000-0001-7742-0255

\section{ABSTRACT}

\section{Objective}

To describe the development of a dentistry school strategy in order to reduce the occupational risk related to hepatitis $B$.

\section{Methods}

The academic registration documents of 242 students entering the institution between the years 2006 and 2013, were evaluated, among which were of copies of the updated vaccination cards and anti-HBs serologic testing. Demographic variables and others related to the vaccination status of hepatitis $B$ and seroconversion were considered.

\section{Results}

One hundred percent of the students were found to be vaccinated, and $87.2 \%$ had vaccination records of three doses. The results of anti-HBs tests proved seroconversion in $91.3 \%$ of the students. From 2011, the dental school was able to institutionalize the follow-up behavior of the students who had anti-HBs non-reactive. Of the twenty individuals whose serology was negative, nine students (45\% of the total and all of the 2011-2013 class) were followed-up and repeated the basic vaccination and anti-HBs test; eight seroconverted and one was considered a non-responder, increasing the percentage of immune students to $95 \%$. Eleven (55\%) had other unregistered behavior or the documents analyzed showed no data on them.

\section{Conclusion}

The procedure of following-up the registration in vaccination records required by the Biosafety Committee of the institution was shown to be effective in reducing the occupational risk of hepatitis $B$ among the students.

Indexing terms: Hepatitis B. Seroconversion. Vaccination.

\section{RESUMO}

\section{Objetivo}

Descrever a experiência de uma Faculdade de Odontologia para redução do risco ocupacional relacionado à hepatite B.

\section{Métodos}

Foram avaliados os documentos de cadastro acadêmico dos 242 alunos com ingresso na instituição entre os anos de 2006 a 2013 , dos quais faziam parte cópias da carteira de vacinação atualizada e do teste sorológico anti-HBs. Variáveis demográficas e relacionadas à situação vacinal da hepatite B e de soroconversão foram consideradas.

\section{Resultados}

Verificou-se que $100 \%$ dos discentes foram vacinados, sendo que para $87,2 \%$ havia registro de vacinação em três doses. Os resultados do antiHBs comprovaram a soroconversão em $91,3 \%$ dos alunos. Dos 20 indivíduos, cuja sorologia foi negativa, 9 alunos (45\% do total e todos das turmas de 2011 a 2013) foram acompanhados e repetiram o esquema básico de vacinação e o teste anti-HBs, sendo que 8 soroconverteram e

\footnotetext{
${ }^{1}$ Faculdade São Leopoldo Mandic, Curso de Odontologia. Programa de Pós-Graduação em Clínicas Odontológicas Integradas. Campinas, SP, Brasil.

${ }^{2}$ Faculdade São Leopoldo Mandic, Curso de Odontologia. Departamento de Farmacologia. Campinas, SP, Brasil.

${ }^{3}$ Faculdade São Leopoldo Mandic, Curso de Odontologia. Departamento de Histologia. Campinas, SP, Brasil.

${ }^{4}$ Faculdade São Leopoldo Mandic, Curso de Odontologia. Departamento de Saúde Pública. Campinas, SP, Brasil. Rua José Rocha Junqueira, 13, Swift, 13045-755, Campinas, SP, Brasil. Correspondência para / Correspondence to: FM FLÓRIO. E-mail: <flaviaflorio@yahoo.com>.

$\checkmark \nabla$ V

Como citar este artigo / How to cite this article

Nogueira DN, Ramacciato JC, Motta RHL, Brito Júnior RB, Silva ASF, Flório FM. Strategy to control occupational risk for hepatitis B: impact on the vaccination and seroconversion rates in dentistry students. RGO, Rev Gaúch Odontol. 2018;66(1):8-14. http://dx.doi.org/10.1590/1981-
} 863720180001000013378 
1 foi considerado não respondedor, elevando a frequência de alunos imunes para 95\%. Os 11 (55\%) restantes não tiveram conduta registrada ou não havia dados sobre os mesmos nos documentos analisados.

\section{Conclusão}

A conduta de acompanhamento vem mostrando-se efetiva para reduzir o risco ocupacional da hepatite B entre os alunos.

Termos de indexação: Hepatite B. Soroconversão. Vacinação.

\section{INTRODUCTION}

Hepatitis B presents universal distribution, and estimates indicate that approximately one third of the world population has been in contact with the hepatitis B virus (HBV) and that there are 325 million chronic carriers. Of these individuals, over 600,000 die every year of acute diseases or chronic sequelae secondary to infection by $\mathrm{HBV}^{1-2}$. Hepatitis B is an important public health problem on all continents ${ }^{3}$.

In Brazil, in spite of the progression of vaccination coverage and increased access to guidance on prevention, approximately 17,000 cases are confirmed every year. In the years 2013 and 2014, 17,814 and 17,940 cases were notified, respectively, indicating stability over the last few years. These records contemplate recent through to old infections, but that were only diagnosed in the mentioned year ${ }^{4}$.

Hepatitis B is an important public health problem on all continents ${ }^{3}$. The prevalence of infection by HBV is higher among dental surgeons than among the population in general, a situation characterizing the disease as an occupational risk for dental professionals ${ }^{5}$. Percutaneous or mucosal tissue exposures to the blood of individuals infected by HBV are the main transmission pathway, because of professionals' exposure to organic fluids and the occurrence of accidents with perforating sharps ${ }^{1,6}$. A high frequency of accidents occurring with biological material has been verified among students in the health area, with dental students being among those most cited $^{7-8}$.

From this aspect, it is recommended that dental surgeons and other health professionals protect themselves from undue risks by means of vaccination against Hepatitis $B$, and confirm immunity by the antiHBs test ${ }^{9-12}$. Moreover, considering that the duration of protection provided by the vaccine persists for up to 22 years, repetition of the serological tests is indicated to evaluate maintenance of immunity throughout professional life. When necessary, individuals immunized by vaccine, who become non-responders to the first scheme, must be re-vaccinated with one or more doses ${ }^{13}$.
Vaccination against hepatitis $B$, with relatively modest costs and high benefits, is an important investment in public health ${ }^{2}$. It is indicated for all health professionals before they are admitted to the workplace, and must preferably be completed before the clinical activities of students begin ${ }^{1,7}$. These professionals must receive the basic scheme of three doses (zero, one and six months); and from one to two months after the last dose, having serology performed is recommended to evaluate seroconversion (anti-HBs $\geq 10 \mathrm{Ul} / \mathrm{ml}$ ) (positive), when no prophylactic action is necessary.

However, if the anti-HBs $<10 \mathrm{Ul} / \mathrm{ml}$ test us negative, the following procedures are recommended: negative serology one to two months after the third dose - repeat the vaccination scheme (zero, one and six months); serology negative, if a long time has passed after the third dose of the first scheme: apply one dose and repeat the serology after one month. Should it be positive, consider the individual immunized; should it be negative, complete the scheme with another two doses; serology negative one to two months after the third dose of the second scheme - do not apply any further vaccination, and consider the individual a susceptible non-responder ${ }^{10,12-13}$.

In view of the foregoing, this study describes the follow-up experiment of the Biosafety Commission of a Higher Learning Institute (HLI) of Dentistry for reducing the occupational risk related to Hepatitis $B$, by means of controlling the vaccine situation and seroconversion of students before they undergo training periods and begin clinical disciplines.

\section{METHODS}

This study was conducted in accordance with the precepts determined by resolution 196/96 of 10/10/96 of the National Health Council of the Ministry of Health, and approval by the Research Ethics Committee of the São Leopoldo Mandic School of Dentistry, Protocol Number 2010/0473.

This was a descriptive, documentary and quantitative study, in which the documents of 242 
students of 8 Groups were evaluated, on entering the Dentistry Course of the São Leopoldo Mandic School of Dentistry, Campinas, SP, in the years from 2006 to 2014.

All the information collected was obtained from the documentation available at the undergraduate course secretariat, because it was institutional policy to request a copy of this documentation as part of the students' registration process. Information about the need for handing in this documentation before the student began clinical activities was provided in the candidate's guide to the entrance examination and in the student enrollment documentation.

The HLI Biosafety Commission followed-up the dates of vaccination and serological test of students who had not been submitted these procedures previously, which was based on the Brazilian Ministry of Health recommendation 10 and that of the Center for Disease Control and Prevention ${ }^{12-13}$. To guarantee the students' adhesion, the Biosafety Commission did not release access of students to practical clinical activities with patients, if their documentation of compliance with the vaccination situation and seroconversion control was not up to date.

Demographic variables (sex, age and undergraduate's age at time of receiving first dose of the vaccine) and variables related to the hepatitis $B$ vaccine situation and seroconversion status: center where vaccine was applied (public or private service); vaccine coverage (dates of doses of vaccine applied; and date/result of anti-HBs exam) were analyzed.

According to the records in the vaccination cards, the interval between the doses of vaccine was calculated, making it possible to assess the compliance with the Ministry of Health recommendation (0, 1 and 6 months) and the interval between the last dose and undergoing the anti-HBs exam for verifying compliance with the time of 1-2 months recommended ${ }^{10}$.

In the case of records contemplating more than 3 doses of vaccine, the interval between the first three doses was used for verifying compliance with the vaccination scheme, and the time elapsed between the last dose received and the anti-HBs test, to evaluate confirmation of the seroconversion status.

For non-reactive individuals, the procedure adopted for implementing a new vaccination scheme and repeating the anti-HBs exam was followed-up.

The interval between doses of vaccine, origin of the vaccine and result of the anti-HBs exam were evaluated by the Chi-square and Exact Fisher tests. Distribution of the anti-HBs values considering the result of the test (reactive or non-reactive), age at the time of handing in the documents, age at the time of vaccination and time elapsed between the vaccination and serological exam were analyzed by the Mann-Whitney test. The Spearman correlation was used to explore the relations between the following values: anti-HBs and present age; age at the time of vaccination and time elapsed between the vaccination and serological exam. For all tests, the level of significance adopted was 5\%. The software GraphPad Prism (version 6.00 for Windows, GraphPad Software, La Jolla, California, USA) was used for all the calculations.

\section{RESULTS}

The documents of all students enrolled between 2006 and 2013 were analyzed, totaling 242 students, of whom 175 (71.9\%) were of the female gender. The mean age of students, in the year in which the documentation was handed in was $20.5( \pm 3.7)$ years.

The majority of students were found to have respected the interval between the doses of vaccine (54.5\%); were vaccinated at the SUS (Brazilian National Health) units $(62.0 \%)$ and presented the anti-HBs reactive test $(91.3 \%)$ (Table 1$)$. Age at the time of vaccination did not differ $(p=0.24)$ between the male $(11.3 \pm 6.8$ years $)$ and female (12.8 \pm 7.5 years) genders. There was no significant association between the "reactive" and "non reactive" groups as regards age at the time of data collection ( $p=0.25)$, age at the time of receiving vaccination $(p=0.19)$ time elapsed between vaccination and the serological exam $(p=0.76)$.

Although significant, the correlations were weak between the anti-HBs values and the variables: present age $(r S=0.14, p=0.0305)$, age at time of vaccination $(r S=0.24$, $\mathrm{p}=0.0002$ ) and time elapsed between vaccination and serological exam $(r S=-0.23, p=0.0004)$. However, it was possible to observe a trend towards direct correlation between the anti-HBs values with both present age and age at the time of vaccination, but there was indirect correlation between the time elapsed between vaccination and the serological exam. This indicated that the older the student (present age or age at the time of vaccination) the higher were the titration values of the anti-HBs exam; however, the longer the time elapsed between the vaccination and serological exam, the lower were these values.

Table 2 shows the distribution of the students in relation to the group of origin; total number of students 
vaccinated $(100 \%)$; number of subjects with vaccination in three doses proved by means of a vaccination card (87.2\%); the result of the anti-HBs exam: reactive (91.3\%) and non-reactive (8.7\%); and the dental school's followup procedure with regard to the re-vaccination data of students who presented Anti-HBs non-reactive. The authors observed that as from 2011, the dental school was able to institutionalize greater care with reference to following-up the "non-reactive" individuals, considering that of the 20 "non-reactive" individuals, 9 (45\% of the total number and all the groups from 2011 to 2013) were followed-up and repeated the vaccination scheme and anti-HBs test; of these, 8 seroconverted and 1 was considered nonresponsive. The 11 (55\%) remaining individuals had no procedure recorded, or there were no data about them in the documents analyzed.

Table 1. Absolute proportion of subjects in relation to interval between doses of vaccine, origin of vaccine, and result of anti-HBs. Campinas (SP), 2015.

\begin{tabular}{|c|c|c|c|c|}
\hline \multirow{2}{*}{ Factors } & \multirow{2}{*}{ Vaccinated } & \multicolumn{2}{|c|}{ Result of Anti-HBs } & \multirow{2}{*}{ p-value } \\
\hline & & Nonimmune & Immune & \\
\hline \multicolumn{5}{|l|}{ Regarding the interval between doses of vaccine } \\
\hline Yes & $132(54.5)$ & $13(65.0)$ & $119(53.6)$ & \\
\hline No & $109(45.0)$ & $6(30.0)$ & $103(46.7)$ & $0.31 *$ \\
\hline \multicolumn{5}{|l|}{ Origin of vaccine } \\
\hline Public & $150(62.0)$ & $13(65.0)$ & $137(61.7)$ & \\
\hline Private & $20(8.3)$ & $2(10.0)$ & $18(8.1)$ & $0.86^{*}$ \\
\hline No information & $72(29.7)$ & $5(25.0)$ & $67(30.2)$ & \\
\hline \multicolumn{5}{|l|}{ Student's Age ${ }^{\&}$} \\
\hline In data collection ${ }^{\&}$ & $20.5 \pm 3.7$ & $21.0 \pm 7.9$ & $20.4 \pm 3.0$ & $0.25^{* *}$ \\
\hline No information & $1(0.4)$ & $1(5.0)$ & - & \\
\hline At time of vaccination\& & $12.9( \pm 7.0)$ & $12.9( \pm 11.0)$ & $12.9( \pm 6.6)$ & $0.19 * *$ \\
\hline Time between vaccination and anti-HBs test \& & $5.7( \pm 5.5)$ & $7.3( \pm 6.7)$ & $5.5( \pm 5.4)$ & $0.76^{* *}$ \\
\hline Total & $242(100.0)$ & $20(8.3)$ & $221(91.3)$ & \\
\hline
\end{tabular}

Note: \& Mean \pm standard deviation (years) * Exact Fisher Test; ** Mann-Whitney test. The values "no information" were not considered.

Table 2. Classification of students about year of entry into dental school, data of vaccination in 3 doses, result of anti-HBs, and presence of revaccination data of Anti-HBs non-reactive. Campinas (SP), 2015.

\begin{tabular}{|c|c|c|c|c|c|c|c|}
\hline \multirow{2}{*}{ Class } & \multirow{2}{*}{ Total } & \multirow{2}{*}{ Vaccinated } & \multirow{2}{*}{$\begin{array}{c}\text { Vaccination data in } 3 \\
\text { doses }\end{array}$} & \multicolumn{3}{|c|}{ Anti-HBs } & \multirow{2}{*}{ Revaccination data } \\
\hline & & & & Immune & Nonimmune & No results & \\
\hline 2007 & 30 & 30 & 24 & 28 & $2(6.7 \%)$ & - & ND \\
\hline 2009 & 35 & 35 & 31 & 34 & $1(2.9 \%)$ & - & ND \\
\hline 2010 & 32 & 32 & 30 & 32 & 0 & - & - \\
\hline 2011 & 27 & 27 & 26 & 21 & $6(22.2 \%)$ & - & Yes \\
\hline Total & $242(100 \%)$ & $242(100 \%)$ & $(87,2 \%)$ & $221(91,3 \%)$ & $20(8.3 \%)$ & $1(0.4 \%)$ & \\
\hline
\end{tabular}

Legend: $\mathrm{ND}=$ revaccination data and / or results of anti $-\mathrm{HBs}$ after revaccination test not available, Yes = data in the registry.

\section{DISCUSSION}

Dental Schools are responsible for the quality of teaching and multiplication of infection control behaviors, adequate training of students with a view to protecting the patient and establishing safe working conditions ${ }^{14-15}$. Therefore, biosafety recommendations are frequently updated and published ${ }^{12,16-17}$.

Infection by HBV is recognized as the most important occupational risk for dental surgeons 6 .
When injuries occur as a result of needles contaminated with blood containing HBV, if the blood were HBsAgpositive and $\mathrm{HBeAg}$-positive, the risk for development of clinical hepatitis is from $22-31 \%$; whereas the risk for developing serological evidence of infection by HBV is from $37-62 \%{ }^{13}$. For this reason, the indication is for all professionals to be immunized before entering into clinical practice. In the case of hepatitis $B$, immunity after the three doses of vaccine is proved when the anti-HBs serological test is $\geq 10 \mathrm{UI} / \mathrm{ml}$, a result that proves the 
presence of antibodies against the disease ${ }^{10,13}$

In the present study, the validity of the data collected by inspecting the vaccination cards and laboratory exam reports allowed adhesion to the vaccination measures to be known, without the possibility of response and memory biases resulting from the use of self-applicable questionnaires, because this was a documentary research. In the majority of studies in the literature, the data result from self-applicable questionnaires that depend on the participant's memory $1,5,14-15,18-20$. In practice, it was only possible to carry out this inspection due to the dental school's demand that students had to hand in a copy of their vaccination card and anti-HBs exam result to the undergraduate course secretariat, so that these could be evaluated, and later attached to the documents of each student. The data surveyed by this study demonstrated the effectiveness of the institutional strategy for increasing the occupational safety of students, since it was possible to guarantee a higher rate of immunization when compared with those of other similar studies, considering that the frequency of students who proved having received the vaccine in three doses was $87.2 \%$, and $99.6 \%$ of anti-HBs tests were performed. The rate of vaccination in three doses was calculated from the number of students who proved they received the 3 doses of vaccination by means of the records in their vaccination card, and by checking the date of each dose applied. Of the $12.8 \%$ of students who were unable to find their card, vaccination was proved by presentation of the anti-HBs exam result that was frequently accompanied by a medical declaration confirming application of the vaccination.

In spite of immunization being strongly recommended, researches have shown that the rate among dental students varies widely in the literature. Among the studies conducted in teaching institutions in Brazil, variation in the immunization rate and confirmation of seroconversion ranged from $41.6 \%$ to $90.8 \%$ and $1.8 \%$ to $25 \%$, respectively ${ }^{14,18,20-22}$. Whereas abroad, the vaccination rates varied ${ }^{15,19,23}$.

When analyzing the immunization rates, the authors of the present study verified that in the majority of dental schools evaluated, the students did not present a spontaneous preventive behavior in relation to hepatitis B. The only dental school where concern about prevention was evident, was in Spain, where immunity was demonstrated in $72.9 \%$ of the students ${ }^{24}$. In the other dental schools, not only were vaccinations incomplete, but there was no concern about the antiHBs test, showing that it was performed at very low rates ranging between zero and $25 \%$. This confirms the presence of the gap described by von Lindeman et al. ${ }^{25}$ between awareness of the importance of vaccination and personal behavior, because incomplete vaccination among students in the health area leads to the risk of increasing infections, consequently requiring stricter demands regarding questions concerning vaccination.

In agreement with the knowledge about the risk of cross infection related to hepatitis $B$, the Institutional Biosafety Commission established a rule for students, demanding that they handed in a copy of the vaccination card proving that they had received the complete scheme of vaccination against hepatitis $B$ and the seroconversion test, before they began with clinical activities. This initiative was based on the $\mathrm{HLI}$ biosafety protocol that was in turn based on the infection control procedures adopted both nationally ${ }^{10,17}$ and internationally ${ }^{12-13,16}$.

Of thestudents, $54.4 \%$ complied with the "interval between doses", and no information was obtained with respect to 1 student. This criterion is controversial in the literature, because it has been demonstrated that intervals longer than those recommended have provided equivalent results. Therefore, although the time interval between doses had not been respected, there was no need to re-initiate the scheme, but it was important to verify the previous vaccination situation ${ }^{26}$. On the other hand, researches have shown that there was association between the fact of respecting the time interval between doses and the serum level of anti-HBs antibodies ${ }^{27}$.

In the present study, $8.26 \%$ of the students presented no immunity after the first scheme of three doses of vaccine, which was close to the value found in similar studies: $11.5 \% 26$ and $12.5 \%{ }^{20}$. Moreover, no association was observed between seroconversion after three doses of vaccine and gender, as was shown in the research of Alavian et al. ${ }^{28}$. However, associations of female gender with higher antibody titer values have been shown, as has been observed in previous studies ${ }^{3,26}$.

The majority of studies have shown that a longer interval of time between the last dose of vaccine and undergoing the anti-HBs test leads to significant impact on the seroprotection indexes, with a better response being obtained when the seroconversion test was performed in up to 6 months after vaccination ${ }^{2,26,28}$.

In a study with professionals, it was observed that individuals who received the third dose of vaccine 
less than 5 years ago had higher titers of antibodies than those who received the last dose longer than 5 years $\mathrm{ago}^{26}$. The levels of anti-HBs after vaccination decline over time, which may be explained by various factors, among them smoking, obesity, aging, chronic diseases, and genetic or immunosuppressive factors ${ }^{2,13,24}$. Among immunocompetent responders, the duration of protection induced by vaccination persists for a period ranging from $15-1829$ up to 22 years ${ }^{13}$. However, in groups at risk, such as Dental students, it is important to implement periodic control of antibody levels every 2-3 years. When anti-HBs tests present results of 10-99 $\mathrm{mlU} / \mathrm{ml}$, the administration of a booster dose of vaccine against hepatitis $B$ is indicated ${ }^{24}$.

Of the 9 non-reactive students who had the revaccination procedure recorded, $88.9 \%$ became immune and $11.1 \%$ was considered a non-responder. One study showed that approximately $60 \%$ of non-responders become immune after the sixth dose of vaccine ${ }^{30}$. This is a differential to be considered in the institutional protocol, because the demand for implementing the second vaccination scheme in the first groups was not shown to be so effective. In the subsequent groups, the re-vaccination protocol was more strictly applied, because access to clinical activities was restricted if students did not hand in the mandatory documentation, thus demonstrating development of the program over the course of time.

To control the risk of hepatitis B in dental environments, sterilization, use of individual protective equipment, and vaccination protocols must be implemented. In teaching institutions, pedagogical efforts accompanied by continuous education must motivate students to use standard precautions correctly and routinely ${ }^{6,15}$. Vaccination against HBV is the measure

\section{REFERENCES}

1. Garcia LP, Blank VLG, Blank N. Aderência a medidas de proteção individual contra a hepatite $B$ entre cirurgiões-dentistas e auxiliares de consultório dentário. Rev Bras Epidemiol. 2007:10(4): 525-36. doi: 10.1590/S1415-790X2007000400011

2. Franco E, Bagnato B, Marino MG, Meleleo C, Serino L, Zaratti L. Hepatitis B: Epidemiology and prevention in developing countries. World J Hepatol. 2012;4(3):74-80. doi: 10.4254/wjh. v4.i3.74

3. Osti C, Marcondes-Machado J. Vírus da hepatite B: avaliação da resposta sorológica à vacina em funcionários de limpeza de hospital-escola. Ciênc Saúde Colet. 2010;15(Supl. 1):13431348. doi: 10.1590/S1413-81232010000700043 for primary prevention and control of the disease, and so is the need for confirming seroconversion of the vaccinated persons $5^{5,10,13}$, thus emphasizing the importance of the demand by HLIs for students to present their vaccination card and seroconversion test results, thereby minimizing the risk in the case of an eventual exposure to infection.

\section{CONCLUSION}

The procedure of monitoring the registration in vaccination records required by the Biosafety Committee of the dental school was shown to be effective in reducing the occupational risk of hepatitis B among students; and the vaccination seroconversion rates obtained were higher when compared with those of similar studies.

\section{ACKNOWLEDGEMENTS}

The present study was sponsored by the researchers' own resources, and our special thanks go to Sra. Madalena Prudêncio, responsible for the undergraduate course secretariat, for her untiring work of guaranteeing that the students handed in their vaccination documentation and proof of seroconversion.

\section{Collaborators}

NUNES is the principal investigator and led the writing of the manuscript. RAMACCIATO, BRITOJUNIOR, MOTTA E FONSECA SILVA are co-investigators and contributed to the writing and revision of the manuscript. FM FLÓRIO is the project manager, coinvestigator and contributed to the writing and revision of the manuscript.

4. Brasil. Ministério da Saúde. Ministério lança campanha contra hepatites virais online. Brasília: Ministério da Saúde; 2015 [citado 2016 Fev 3]. Disponível em: <http://www.brasil.gov.br/ saude/2015/07/ministerio-lanca-campanhas-contra-hepatitesvirais>.

5. Ferreira RC, Guimarães ALS, Pereira RD, Andrade RM, Xavier RP, Martins AMEBL. Vacinação contra hepatite $B$ e fatores associados entre cirurgiões-dentistas. Rev Bras Epidemiol. 2012;15(2):315323. doi: 10.1590/S1415-790X2012000200009

6. Dahiya P, Kamal R, Sharma V, Kaur S. "Hepatitis": prevention and management in dental practice. J Edu Health Promot. 2015;4:33. doi: 10.4103/2277-9531.157188

7. Gir E, Netto JC, Malaguti SE, Canini SRMS, Hayashida M, Machado AA. Acidente com material biológico e vacinação 
contra hepatite $B$ entre graduandos da área da saúde. Rev Latino-Am Enfermagem Online. 2008;16(3). doi: 10.1590/ S0104-11692008000300011

8. Orestes-Cardoso SM, Farias ABL, Pereira MRMG, OrestesCardoso AJ, Cunha Júnior IF. Acidentes perfurocortantes: prevalência e medidas profiláticas em alunos de odontologia. Rev Bras Saúde Ocup. 2009;34(119):6-14. doi: 10.1590/S030376572009000100002

9. Brasil. Ministério do Trabalho e Emprego. Portaria n. 485, de 11 de novembro de 2005. Aprova a Norma Regulamentadora - NR 32, relativa à Segurança e Saúde no Trabalho em Serviços de Saúde. Diário Oficial da República Federativa do Brasil, Brasília, 16 de nov. 2005.

10. Brasil. Ministério da Saúde. Secretaria de Vigilância em Saúde. Departamento de Vigilância das Doenças Transmissíveis. Manual dos Centros de Referência para Imunobiológicos Especiais. $4^{a}$ ed. Brasília: Ministério da Saúde; 2014.

11. World Health Organization. Guidelines for the prevention, care and treatment of persons with chronic hepatitis B infection. Geneva: WHO Press, World Health Organization; 2015.

12. Centers for Disease Control and Prevention. CDC Recommendations from the Guidelines for Infection Control in Dental Health-Care Settings - 2003. Atlanta: US Department of Health and Human Services, Centers for Disease Control and Prevention, National Center for Chronic Disease Prevention and Health Promotion, Division of Oral Health; 2016.

13. Schillie S, Murphy TV, Sawyer M, Ly K, Hughes E, Jiles R. CDC Guidance for Evaluating Health-Care Personnel for Hepatitis $B$ Virus Protection and for Administering Postexposure Management. MMWR Recomm Rep. 2013;62(10):1-19.

14. Souza RA, Namen FM, Galan J Jr, Vieira C, Sedano HO. Infection control measures among senior dental students in Rio de Janeiro State, Brazil. J Public Health Dent. 2006;66(4):282-4.

15. Halboub ES, Al-Maweri SA, Al-Jamaei AA, Tarakji B, Al-Soneidar WA. Knowledge, attitudes, and practice of infection control among dental students at Sana'a University, Yemen. J Int Oral Health. 2015;7(5):15-19.

16. Kohn WG, Collins AS, Cleveland JL, Harte JA, Eklund KJ, Malvitz DM, Centers for Disease Control and Prevention (CDC). Guidelines for infection control in dental healthcare settings 2003. MMWR Recomm Rep. 2003;52(RR17):1-61.

17. Brasil. Agência Nacional de Vigilância Sanitária. Serviços Odontológicos: prevenção e controle de riscos. Brasília: Editora Anvisa; 2006.

18. Angelo AR, Queiroga AS, Gonçalves LFF, Santos SD, Sousa CFS, Soares MSM. Hepatite B: conhecimento e prática dos alunos de odontologia da UFPB. Pesq Bras Odontoped Clin Integr. 2007;7(3):211-216.

19. Kumar S, Basak D, Kumar A, Dasar P, Mishra P, Kumar A, et al. Occupational hepatitis b exposure: a peek into indian dental students' knowledge, opinion, and preventive practices. Interdiscip Perspect Infect Dis. 2015;2015:190174. doi: $10.1155 / 2015 / 190174$
20. Sacchetto MSLS, Barros SSLV, Araripe TA, Silva AM, Faustino SKM, Silva JMN. Hepatitis B: knowledge, vaccine situation and seroconversion of dentistry students of a public university. Hepat Mon 2013;13(10):1-7. doi: 10.5812/hepatmon.13670

21. Soriano EP, Carvalho MVD, Carneiro GR, Guimarães LL, Santos FB. Hepatite B: avaliação de atitudes profiláticas frente ao risco de contaminação ocupacional. Odontol Clín-Cient. 2008;7(3):227-234

22. Granville-Garcia AF, Batista BB, Cavalcanti AL, D'Avila S, Lins RDAU, Menezes VA. Adesão e conhecimento de medidas de proteção individual contra a hepatite $B$ entre estudantes de odontologia. Odontol Clin Sci. 2009;8(4):325-330.

23. Sofola OO, Folayan MO, Denloye OO, Okeigbemen SA. Occupational exposure to bloodborne pathogens and management of exposure incidents in Nigerian dental schools. J Dent Educ. 2007;71(6):832-7.

24. Arias-Moliz MT, Rojas L, Liébana-Cabanillas F, Bernal C, Castillo F, Rodríguez-Archilla A, et al. Serologic control against hepatitis $B$ virus among dental students of the University of Granada, Spain. Med Oral Patol Oral Cir Bucal. 2015;20(5):e566-71. doi: 10.4317/medoral.20579

25. von Lindeman K, Kugler J, Klewer J. Vaccinations among students in health care professions. Pflege Z. 2011;64(12):7403.

26. Momeni N, Akhoundi MSA, Alavian SM, Shamshiri, AR, Norouzi, $M$, Mahboobi $N$, et al. HBV vaccination status and response to hepatitis B vaccine among iranian dentists, correlation with risk factors and preventive measures. Hepatitis Monthly 2015;15(1):1-7. doi: 10.5812/hepatmon.20014. eCollection 2015

27. São Paulo. Secretaria de Estado da Saúde de São Paulo. Divisão de Imunização. Divisão de Hepatites. Centro de Vigilância Epidemiológica "Prof. Alexandre Vranjac". Coordenadoria de Controle de Doenças. Vacina contra hepatite B. Rev Saúde Pública. 2006:40(6):1137-1140.

28. Alavian SM, Mahboobi N, Mahboobi N. Anti-HBs antibody status and some of its associated factors in dental health care workers in Tehran University of Medical Sciences. Hepat Mon. 2011;11(2):99-102.

29. Lu CY, Ni YH, Chiang BL, Chen PJ, Chang MH, Chang LY, et al. Humoral and cellular immune responses to a hepatitis $B$ vaccine booster 15-18 years after neonatal immunization. J Infect Dis. 2008;197(10):1419-1426. doi: 10.1086/587695

30. Lopes MH, Sartori AMC, Souza TVG, Mascheretti M, Chaves TSS. Hepatite B revacinação para os trabalhadores de saúde que são anti-HBs-negativos depois de receber uma série de vacinação primária. Rev Soc Bras Med Trop. 2012;45(5):639642. 